\title{
APSEK PENANGANAN SAMPAH DALAM PENERAPAN PRINSIP GREEN BUILDING (STUDI KASUS PADA BANGUNAN RUKO DI KUPANG)
}

\author{
Theresia A. Bria ${ }^{1}$, Tedy Wonlele ${ }^{2}$, dan Melchior Bria ${ }^{3}$ \\ ${ }^{1}$ Jurusan Teknik Sipil Politeknik Negeri Kupang \\ E-mail: theresia.bria@pnk.ac.id \\ 2 Jurusan Teknik Sipil Politeknik Negeri Kupang \\ E-mail: tedy_wonlele@pnk.ac.id \\ ${ }^{3}$ Jurusan Teknik Sipil Politeknik Negeri Kupang \\ E-mail: melchior.bria@pnk.ac.id
}

\begin{abstract}
Abstrak
Bangunan Rumah Toko atau sering disingkat Ruko, tumbuh pesat di perkotaan sebagai imbas dari meningkatnya perekonomian suatu wilayah. Bahkan tidak hanya di kota, telah pula merambah hingga pedesaan, mengubah fungsi lahan pertanian menjadi bangunan Ruko. Hal ini jika tidak ditangani secara baik akan menimbulkan dampak yang negative jika dilakukan dalam skala besar dan bersifat massif. Untuk itu penelitian ini menggambarkan bagaimana pembangunan gedung merespon adanya prinsip green building yang tertuang dalam green building council khusus dalam hal penanganan sampah/limbah konstruksi. Hasil penelitian menunjukkan bahwa hanya $21 \%$ dari prinsip green building council dalam hal penanganan sampah yang diterapkan oleh pemilik maupun pelaksana pembangunan Rumah Toko. Sedangkan dai kriteria Prinsip Green Building Council dari aspek penanganan sampah, menurut responden memiliki tingkat kepentingan yang kuat sampai sangat kuat terhadap kriteria yang ada.
\end{abstract}

Kata kunci: Ruko, sampah, konstruksi.

\section{PENDAHULUAN}

Bangunan Rumah Toko atau sering disingkat Ruko, tumbuh pesat di perkotaan sebagai imbas dari meningkatnya perekonomian suatu wilayah. Bahkan tidak hanya di kota, telah pula merambah hingga pedesaan, mengubah fungsi lahan pertanian menjadi bangunan Ruko. Keberadaannya dari sisi ekonomi, bisa dimaknai sebagai sutau kemajuan atau pertumbuhan. Sisi lain, bisa juga dipandang sebagai kemunduran jika membawa konsep green building, karena kebanyakan tanpa analisa dampak lingkungan yang serius atau sekadar memenuhi syarat administrasi. Salah satu yang paling menonjo; adalah beralihya fungsi lahan yang tadinya adalah lahan pertanian menjadi kawasan perumahan/industri/pertokoan. Fenomena ini semakin diperparah dengan pembangunan infrastruktur yang tidak memperhatikan aspekaspek keberlanjutan pembangunan seperti penggunaan material yag ramah lingkungan, dan penanganan limbah akibat kegiatan konstruksi.

Penelitian ini bermaksud mengkaji bagaimana pembangunan infrastruktur khususnya pembangunan bangunan pertokoan dengan konsep Rumah Toko, mampu memberikan kontribusi terhadap penerapan prinsip Green Building Council khususnya dalam penanganan sampah atau limbah konstruksi pada proyek konstruksi khususnya bangunan Rumah Toko.

Proyek itu sendiri didefinisikan sebagai suatu usaha/aktifitas yang kompleks, tidak rutin, dibatasi oleh waktu, anggaran, resources dan spesifikasi perfomansi yang dirancang untuk memenuhi kebutuhan konsumen. Karena itu aktifitas proyek diarahkan utuk mencapai tujuan, sasaran dan harapanharapan penting dengan menggunakan anggaran dan sumber daya yang tersedia dan harus diselesaikan dalam jangka waktu tertentu (Nurhayati, 2010).

Pada kegiatan proyek konstruksi, selain menimbulkan kerusakan alam, kegiatan konstruksi juga menghasilkan limbah yang cukup banyak. Ervianto (2012 ),mengemukakan bahwa : Besarnya limbah konstruksi jika dihitung setiap luasan bangunan adalah $19,5 \mathrm{~kg} / \mathrm{m} 2$ akibat aktivitas pembangunan proyek baru, sedangkan akibat pembongkaran bangunan adalah $757 \mathrm{~kg} / \mathrm{m} 2$. Dalam beberapa proyek, material yang dapat 
didaur ulang seperti kayu, beton, bata merah, metal mencapai $75 \%$ dari total limbah.

Oleh karena itu perlu dikaji bagaimana penerapan prinsip penanganan sampah konstruksi berdasarkan prinsi Green Building Council sebagai suatu kerangka dasar dalam membangun suatu model penanganan sampah yang sistematis dan terintgrasi secara menyeluruh.

\section{METODE PENELITIAN}

Penelitian ini difokuskan pada bangunan bertingkat Rumah Toko Ruko pada wilayah Sekitar Kota dan Kabupaten Kupang dan tidak ada batasan luasan bangunan. Data untuk analisis diperoleh darai pengisian kuesioner oleh Responden, yaitu para pemilik bangunan, penanggung jawab pelaksana pembangunan masing-masing Rumah Toko, dan pengawas pelaksanaan pekerjaan konstruksi.

Kriteria yang digunakan adalah seperti table berikut :

Tabel 1 Kriteria Penanganan Sampah berdasarkan Green Building Council

\begin{tabular}{|c|c|}
\hline No. & KRITERIA \\
\hline 1 & $\begin{array}{c}\text { Adanya Standar Prosedur Operasi, } \\
\text { Pelatihan dan Laporan untuk } \\
\text { mengumpulkan dan memilah sampah } \\
\text { berdasarkan jenis organik dan } \\
\text { anorganik dalam 6 bulan terakhir } \\
\text { untuk sertifikasi perdana }\end{array}$ \\
\hline 2 & $\begin{array}{c}\text { Jika telah melakukan pemilahan } \\
\text { organik dan anorganik, melakukan } \\
\text { pengolahan sampah organik secara } \\
\text { mandiri atau bekerja sama dengan } \\
\text { badan resmi pengolahan limbah } \\
\text { organik. }\end{array}$ \\
\hline 3 & $\begin{array}{c}\text { Jika telah melakukan pemilahan } \\
\text { organik dan anorganik, melakukan } \\
\text { pengolahan sampah anorganik secara } \\
\text { mandiri atau bekerja sama dengan } \\
\text { badan resmi pengolahan limbah } \\
\text { anorganik yang memiliki prinsip 3R } \\
\text { (Reduce, Reuse, Recycle). }\end{array}$ \\
\hline 5 & $\begin{array}{c}\text { Adanya upaya pengurangan sampah } \\
\text { kemasan yang terbuat dari styrofoam } \\
\text { dan non-food grade plastic. }\end{array}$ \\
\hline $\begin{array}{c}\text { Adanya upaya penanganan sampah } \\
\text { dari kegiatan renovasi ke pihak ketiga } \\
\text { minimal 10\% dari total anggaran } \\
\text { renovasi dalam 6 bulan terakhir untuk } \\
\text { sertifikasi perdana*. }\end{array}$ \\
\hline 5
\end{tabular}

6

\begin{tabular}{|l|}
6 \\
\\
\\
\hline 7 \\
\hline \\
\end{tabular}

Kriteria/Faktor
Adanya Standar Prosedur Operasi, Pelatihan dan Laporan manajemen pengelolaan limbah B3 antara lain: lampu, batere, tinta printer dan kemasan bekas bahan pembersih dalam 6 bulan terakhir untuk sertifikas perdana*.

Adanya Standar Prosedur Operasi dan laporan penyaluran barang bekas yang masih dapat dimanfaatkan kembali berupa furniture, elektronik, dan suku cadang melalui donasi atau pasar barang bekas dalam 6 bulan terakhir untuk sertifikasi perdana*. disusun dalam suatu Kuesioner yang didesain sedemikian rupa sehingga pilihan jawaban akan menghasilkan skor berdasarkan tingkat kepentingannya terhadap substansi pertanyaan kuesioner.

Skor yang dipakai dalam kuesioner adalah menggunakan angka dari $1-5$ untuk menyatakan tingkatan pengaruh berdasarkan skala Likert, yaitu :

1. Skor 5 untuk menyatakan tingkatan sangat penting

2. Skor 4 untuk menyatakan tingkatan penting

3. Skor 3 untuk menyatakan tingkatan cukup penting

4. Skor 2 untuk menyatakan tingkatan tidak penting

5. Skor 1 untuk menyatakan tingkatan sangat tidak penting

Selanjutnya kemudian disajikan dalam bentuk grafik distribusi penilaian responden terhadap Kriteria Penanganan Samapah berdasarkan Prinsip Green Building Council.

\section{HASIL DAN PEMBAHASAN}

Dari hasil pengamatan, pada beberapa pekerjaan pembangunan Rumah Toko dan dari hasil maka dapat dipetakan jenis material konstruksi yang menjadi limbah sebagai berikut Limbah kayu bekisting , Papan bekas bowplank , Perancah bamboo, Potongan besi tulangan, Potongan kaca , Potongan keramik, homogenous tile, Gypsum Board, Kalsiboard, Pecahan bata, beton, Pecahan genteng, Sisa mortar, Bungkus semen, Kaleng cat, Plastik, Kertas , Paku, Limbah Cair Genangan air semen, sisa oli,minyak bekisting, sisa cat. Dari berbagai jenis limbah tersebut dapat dikelompokan menjadi limbah padat dan cair, dengan prosentase rata-rata limbah padat $85 \%$ dan limbah cair $15 \%$.

$$
\text { Selanjutnya dari Tabel } 1 \text { prinsip }
$$


Greenship Building Council ditinjau dari aspek Penangnan sampah berdasarkan persepsi responden masih sangat kurang diterapkan pada bangunan Rumah Toko mengingat keberadaanya yang semakin banyak dan cenderung memproduksi sampah dalam jumlah yang cukup signifikan.l.

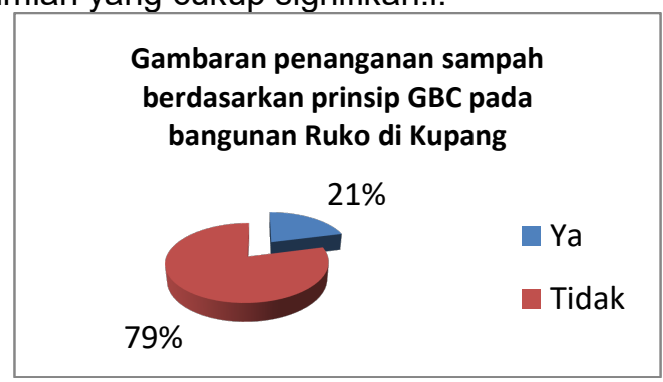

Gambar 1. Prosentase penerapan prinsip GBC dari aspek penanganan sampah/limbah pada bangunan RUKO di Kupang

Hasil survey ini menunjukkan bahwa ternyata dalam hal penanganan sampah bangunan Ruko di Kota Kupang belum secara baik mengelolanya. Hal ini ditandai dengan hanya sekitar $21 \%$ dari prinsip GBC yang dapat diterapkan sedangkan $79 \%$ dari prinsip GBC tidak dapat diterapkan dengan baik oleh pengelola/pemilik Rumah Toko.

Sedangkan untuk

lebih menggambarkan kondisi penanganan sampah pada bangunan rumah toko maka perlu diidentifikasi tingkatan pengaruh dari kriteriakriteria penanganan sampah yang dikeluarkan oleh Green Building Council. Dengan menentukan tingkatan pengaruh ini, diharapkan akan diperoleh suatu model pengambilan keputusan dalam penentuan penanganan sampah

Pada kriteria pertama yaitu Adanya Standar Prosedur Operasi, Pelatihan dan Laporan untuk mengumpulkan dan memilah sampah berdasarkan jenis organik dan anorganik dalam 6 bulan terakhir untuk sertifikasi perdana, responden yang menjawab Sangat Tidak Penting sebesar 9,38\%, Tidak Penting 34,38\%, Cukup Penting 31,25\%, Penting $12,5 \%$ dan Sangat Penting $12,5 \%$.

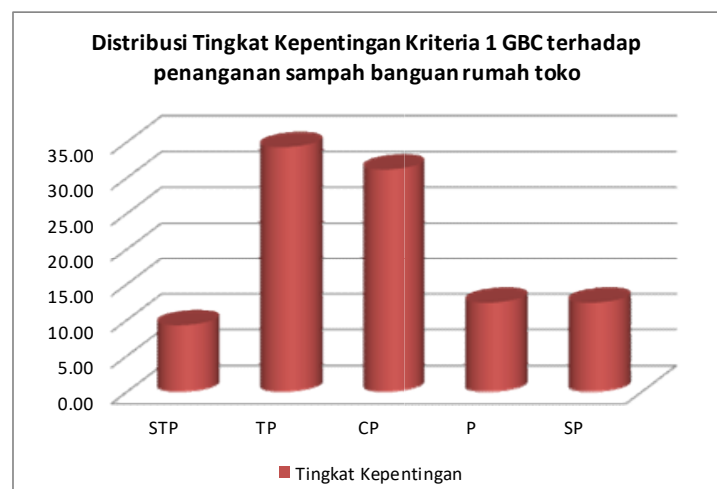

Gambar 2 Hasil Penilaian Tingkat Kepentingan Kriteria 1

Selanjutnya pada kriteria kedua yaitu "Jika telah melakukan pemilahan organik dan anorganik, melakukan pengolahan sampah organik secara mandiri atau bekerja sama dengan badan resmi pengolahan limbah organic' responden yang menjawab sangat tidak penting sebanyak $0 \%$, Tidak Penting $0 \%$, Cukup Penting 18,75\%, Penting 12,5\% dan Sangat Penting $68,75 \%$.

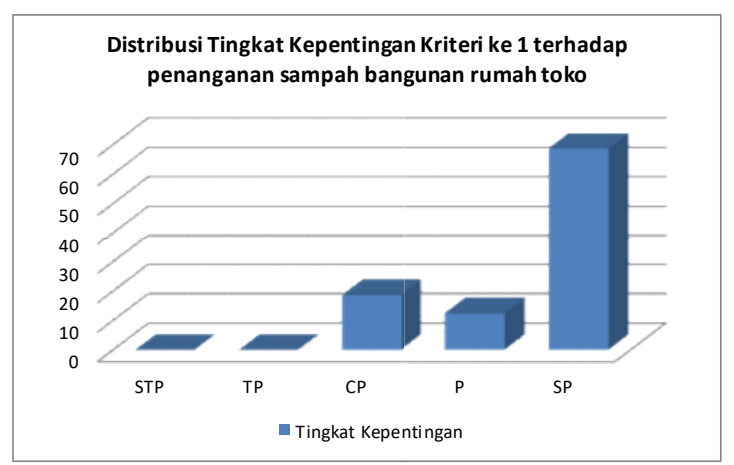

Gambar 3 Hasil Penilaian Tingkat Kepentingan Kriteria ke 2

Pada kriteria ke 3 yaitu "Jika telah melakukan pemilahan organik dan anorganik, melakukan pengolahan sampah anorganik secara mandiri atau bekerja sama dengan badan resmi pengolahan limbah anorganik yang memiliki prinsip 3R (Reduce, Reuse, Recycle)", Responden yang menjawab sangat tidak penting $0 \%$, Tidak Penting $3,12 \%$, Cukup Penting $21,88 \%$, Pentingd $37,5 \%$ dan Sangat Penting $37,5 \%$. 


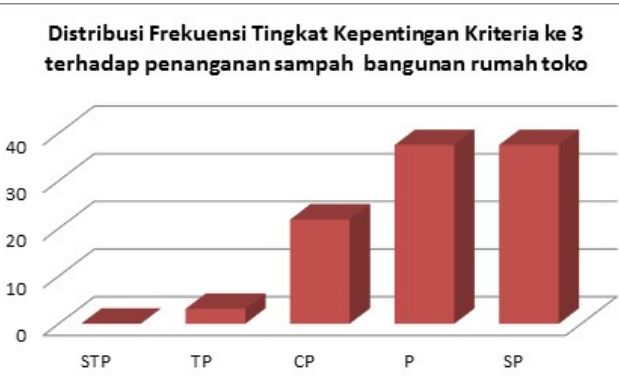

Gambar 4 Hasil Penilaian Tingkat Kepentingan Kriteria ke 3

Pada kriteria ke 4 yaitu "Adanya upaya pengurangan sampah kemasan yang terbuat dari styrofoam dan non-food grade plastic", responden yang menjawab Sanagat Tidak Penting, Tidak Penting dan Cukup Penting sebanyak $0 \%$, sedangkan yang menjawab Penting sebanyak $84,38 \%$ serta responden yang menjawab Sangat Penting sebanyak $15,62 \%$.

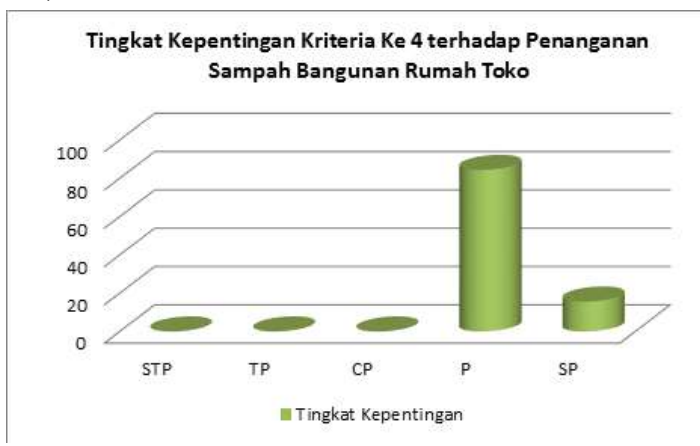

Gambar 5 Tingkat kepentingan Kriteria ke 4

Pada kriteria ke 5 yairu "Adanya upaya penanganan sampah dari kegiatan renovasi ke pihak ketiga minimal $10 \%$ dari total anggaran renovasi dalam 6 bulan terakhir untuk sertifikasi perdana", responden yang menjawab Sangat Tidak Penting dan Tidak Penting sebanyak $0 \%$, Cukup Penting sebanyak $87,5 \%$, sedangkan yang menjawab Penting sebanyak $12,5 \% \%$ serta responden yang menjawab Sangat Penting sebanyak 0\%.
Tingkat Kepentingan Kriteria ke 5 terhadap Penanganan Sampah Bangunan Rumah Toko

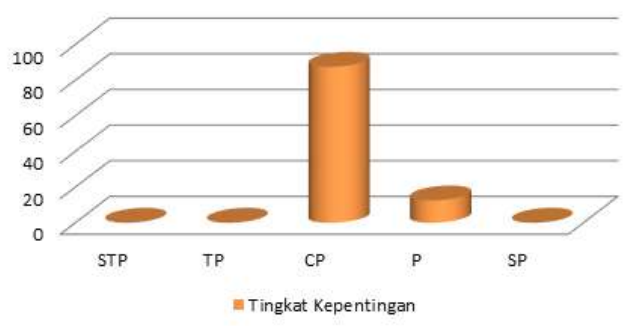

Gambar 6 : Tingkat Kepentingan Kriteria ke 5

Pada kriteria ke 6 yaitu "Adanya Standar Prosedur Operasi, Pelatihan dan Laporan manajemen pengelolaan limbah B3 antara lain: lampu, batere, tinta printer dan kemasan bekas bahan pembersih dalam 6 bulan terakhir untuk sertifikasi perdana", responden yang menjawab Sangat Tidak Penting sebanyak $6,25 \%$, Tidak Penting sebanyak $37,5 \%$, Cukup Penting sebanyak $56,25 \%$, sedangkan yang menjawab Penting sebanyak dan Sangat Penting sebanyak $0 \%$.

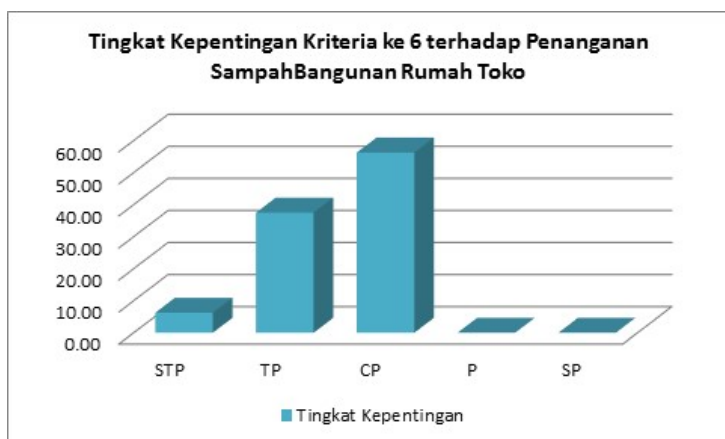

Gambar 7 Tingkat kepentingan Keiteria ke 6

Pada kriteria ke 7 yaitu "Adanya Standar Prosedur Operasi dan laporan penyaluran barang bekas yang masih dapat dimanfaatkan kembali berupa furniture, elektronik, dan suku cadang melalui donasi atau pasar barang bekas dalam 6 bulan terakhir untuk sertifikasi perdana", responden yang menjawab Sangat Tidak Penting sebanyak 9,38\%, Tidak Penting sebanyak $31,25 \%$, Cukup Penting sebanyak $31,25 \%$, sedangkan yang menjawab Penting sebanyak $15,63 \%$ dan Sangat Penting sebanyak $12,5 \%$.. 


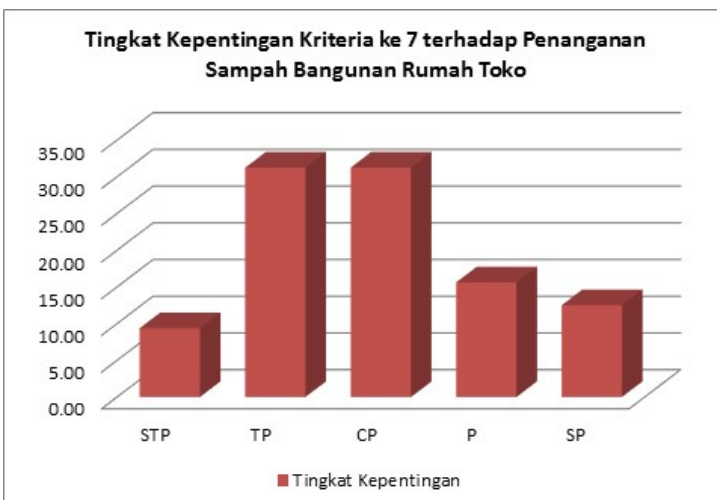

Gambar 8 Tingkat kepentngan Kritera ke 7

\section{PENUTUP} bahwa

Dari Uraian di atas dapat disimpulkan

1. Penerapan prinsip Green Building dalam penanganan sampah masih jauh dari harapan dimana sekitar $21 \%$ dari bangunan Rumah Toko yang menerapkan prinsip green building dalam penanganan sampah.

2. Sedangkan ditinjau dari tingkat kepentingan kriteria / prinsip green building untuk penanganan sampah maka semua kriteria yang ada pada prinsip Green Building umumnya memiliki tingkat kepentingan yang sangat kuat hingga kuat.

Hal ini menunjukkan bahwa walaupun penerapan prinsip green building council masih rendah tetapi respon menyadari bahwa kriteria green building dalam hal penanganan sampah itu penting..

\section{DAFTAR PUSTAKA}

Ervianto, W. I., 2012, Kajian Aspek Keberlanjutan Material Konstruksi Jembatan Selat Sunda, Makalah Seminar Nasional Teknik Sipil UMS

Ervianto, W. I., Soemardi, B. W., Abduh, M. \& Surjamanto (2012). Kajian Aspek Green Construction Pada Pembangunan Proyek Infrastruktur.Konferensi Nasional Infrastruktur. Jakarta, 9 Mei 2012.
Green Building Council Indonesia, 2010, GREENSHIP Homes Rating Tools untuk Rumah Tinggal versi 1.0. Retrieved December 21, 2014 from http://www.greenshiphomes.org/ tabela, A. (2012). Building Materials and The Environment.

Hastuti, Sri Pudji, 2015, Waste Management pada Proyek Pembangunan Gedung sebagai Bagian dari Upaya Perwujudan Green Construction (Studi Kasus : Pembangunan GedungGedung di Universitas Sebelas Maret Surakarta), Jurnal FKIP UNS, www.jurnal.fkip.uns.ac.id/index.php/pt b/article/download/.../3682

Hermawan, dkk, 2013, Peran Life Cycle Analysis (LCA) pada Material Konstruksi dalam Upaya Menurunkan Dampak Emisi Karbondioksida pada Efek Gas Rumah Kaca, Konferesi Nasional Teknik Sipil 7, Uinversitas Sebelas Maret

Nuhayati, 2010, Manajemen Proyek, Graha IImu

Ottong, A. S, dkk, (2014). Penerapan Konsep Sustainable pada Rumah Tinggal dari Segi Material. Surabaya, Indonesia.

Suprapto, H., 2009, Studi Model Pengelolaan Limbah Konstruksi dalam Pelaksanaan Pembangunan Proyek Konstruksi, Proceeding PESAT (Psikologi, Ekonomi, Sastra, Arsitektur \& Sipil) Vol. 3 Oktober 2009 Universitas Gunadarma - Depok, 2021 Oktober 2009

Suriptono, 2014, Teknik Sipil. Menghadirkan Konstruksi Hijau. Presentasi Kuliah Umum 12 Maret 2014 di UK Petra, Surabaya.

World Commission on Environment and Development, 1987, Our Common Future, Report of the World Commission on Environment and Development, Development and International Co-operation: Environment August 2, 1987. 